Jurnal Health Sains: p-ISSN: 2723-4339 e-ISSN: 2548-1398

Vol. 2, No. 6, Juni 2021

\title{
PENGARUH KEPEMIMPINAN KEPALA RUANGAN, BEBAN KERJA SERTA BUDAYA ORGANISASI TERHADAP STRES KERJA PERAWAT RUANG RAWAT INAP RSAU DR. ESNAWAN ANTARIKSA
}

\section{Desi Sofiana, Sandra Dewi, Muhamad Arrozi}

Fakultas Ilmu-Ilmu Kesehatan Universitas Esa Unggul, Jakarta, Indonesia

Email: sofianadesi20@gmail.com, sandra@esaunggul.ac.id, arrozi@esaunggul.ac.id

\begin{tabular}{ll}
\hline ARTIKEL INFO & ABSTRACT \\
\hline Diterima: 5 Juni 2021 & The success of a hospital is strongly influenced by its human \\
Dievisi: 15 Juni 2021 & resources, nurses are the largest human resources in the \\
Disetujui: 25 Juni 2021 & hospital, therefore nurses are the spearhead of the hospital in \\
\hline Keywords: & the process of health services but sometimes nurses also \\
leadership; workload; & experience stress in working, especially inpatient nurses. This \\
organizational culture & study aims to influence the leadership of the head of the room, \\
& workload and culture of the organization to the work stress of \\
& inpatient room nurses hospital or space hospital. This study \\
& uses quantitative research method using causality survey \\
& approach. This suggests that workload needs to be improved \\
& on indicators measured against work stress, while for \\
& leadership and culture the organization needs to be \\
& maintained or leveled so as to lower the work stress of \\
& inpatient nurses. Based on data analysis and discussion of the \\
& results of the study, it can be concluded that the variables of \\
& leadership, workload and organizational culture directly or \\
& simultaneously affect the work stress of rsau inpatientroom \\
& nurses dr. Esnawan Antariksa, which means that the better the \\
leadership, workload and culture of the organization, the \\
lower the work stress.
\end{tabular}

\begin{abstract}
ABSTRAK
Keberhasilan suatu rumah sakit sangat dipengaruhi oleh sumber daya manusianya, perawat merupakan sumber daya manusia yang paling besar yang ada di rumah sakit, oleh karena itu perawat merupakan ujung tombak rumah sakit dalam proses pelayanan kesehatan namun terkadang perawat juga mengalami stres dalam bekerja khususnya perawat ruang rawat inap. Penelitian ini bertujuan untuk pengaruh kepemimpinan kepala ruangan, beban kerja serta budaya organisasi terhadap stres kerja perawat ruang rawat inap rsau dr. esnawan antariksa. Penelitian ini menggunakan metode penelitian kuantitatif dengan menggunakan pendekatan survey kausalitas. Hal ini menunjukkan bahwa beban kerja perlu dilakukan perbaikan pada indikator yang di ukur terhadap stres kerja, sementara untuk kepemimpinan dan budaya organisasi perlu dipertahankan atau ditingkat sehingga menurunkan stres kerja perawat ruang rawat inap.

Berdasarkan analisis data dan pembahasan hasil penelitian,
\end{abstract}

\begin{tabular}{ll}
\hline How to cite: & Sofiana, Desi. et, al. (2021) Pengaruh Kepemimpinan Kepala Ruangan, Beban Kerja serta Budaya \\
& Organisasi Terhadap Stres Kerja Perawat Ruang Rawat Inap RSAU dr. Esnawan Antariksa. Jurnal \\
& Health Sains 2(6). https://doi.org/10.46799/jhs.v2i6.185 \\
E-ISSN: & 2723-6927 \\
Published by: & Ridwan Institute
\end{tabular}


dapat disimpulkan variabel kepemimpinan, beban kerja serta budaya organisasi secara langsung atau simultan berpengaruh terhadap stres kerja perawat ruang rawat inap RSAU dr.

Kata Kunci:

kepemimpinan; beban kerja; budaya organisasi
Esnawan Antariksa, yang artinya semakin baik kepemimpinan, beban kerja serta budaya organisasi maka stres kerja akan semakin rendah.

\section{Pendahuluan}

Rumah sakit merupakan sebuah organisasi pelayanan jasa yang sifatproduknya intangible (tidak bisa dilihat) tetapi bisa dirasakan. Pelayanan langsung diberikan oleh karyawan yang bekerja selama 24 jam dengan tanggung jawab profesi yang berat kerena berhubungan langsung dengan jiwa manusia (Satrianegara, 2014). Perawatmerupakan salah satu komponen mempunyai peran penting dalam memberikan pelayanan kesehatan di rumah sakit dan perawat mempunyai intensitas interaksi paling tinggi dengan pasien dan keluarga dalam memberikan pelayanan kesehatan. Intensitas yang tinggi antara pasien dan keluarga merupakan salah satu pemicu timbulnya stres kerja pada perawat menurut hasil penelitian (Siringoringo \& Fujino, 2015). Sumber- sumber potensi stres antara lain, faktor lingkungan, organisasi (beban kerja, kondisi

/budaya kerja) maupun faktor personal (pengalaman / lamanya bekerja, dan lain-lain) (P. D. Robbins \& Morelli, 2014).

Menurut hasil penelitan dari WHO (Yana, 2015) Perawat tidak bisa memberikan pelayanan yang terbaik bagi rumah sakit dan pada akhirnya akan mempengaruhi daya saing mereka di pasar dan lebih dari itu bahkan dapat membahayakan kelangsungan organisasi rumah sakit. Pengaruh stres kerja pada perawat memiliki pengaruh terhadap profesionalitas perawat dalam melayani pasien. Ketika indikasi stres kerja ini sudah muncul pada perawat, maka mereka cenderung memiliki kinerja yang buruk dalam hal kualitas perawatan pasien, seperti kurang kosentrasi, mudah lelah dan bahkan terkadang muncul perilaku-perilaku yang kurang professional, sehingga pelayanan terhadap klien menjadi kurang optimal. Bentuk perilaku kerja yang kurang professional akan nampak pada bentuk pelayanan yang akan diberikan kepada pasien menurut hasil penelitian (Aini, 2013) dan (Zainaro et al., 2017). Pengelolaan sumber daya manusia termasuk tenaga keperawatan di RSAU dr. Esnawan Antariksa memiliki keunikan yaitu terdapat tenaga perawat yang militer dan non militer dengan sistim penugasan sesuai dengan profesinya sebagai tenaga perawat dan sebagai anggota militer.

Masalah yang muncul dalam observasi ini adalah menurut pimpinan kepala ruangan bahwa perawat yang bekerja di ruangan rawat inap sering mengalami beberapa gejala stres kerja yang dapat mengganggu pelaksanaan kerja mereka seperti sulit berkonsentrasi pada pekerjaan, merasa lelah dalam bekerja. Kebanyakan perawat rawat inap mengalami stres karena ketidakjelasan tugas, hal ini didukung dengan banyaknya pekerjaan yang harus dilakukan, beban kerja perawat yang tinggi, jam kerja yang minimal. Kepemimpinan kepala ruangan dengan tuntutan pelayanan menjadi perawat professional dan adanya kecenderungan gaya kepemimpinan militeristik hal ini disebabkan karena profesi perawat merupakan tenaga kesehatan yang paling tinggi intensitas interaksinya dengan pasien terutama saat berinteraksi dengan pasien yang berasal dari pejabat dan sering berhadapan dengan situasi yang dapat menyebabkan terjadinya stres kerja.

Dalam budaya organisasinya rumah sakit telah menerapkan bahwa pekerja tidak boleh datang terlambat, harus menggunakan 
Pengaruh Kepemimpinan Kepala Ruangan, Beban Kerja serta Budaya Organisasi Terhadap Stres Kerja Perawat Ruang Rawat Inap Rsau Dr.Esnawan Antariksa

seragam lengkap dan memakai seragam yang harus sesuai dengan hari yang ditentukan, saat perawat ijin atau sakit harus disertai surat keterangan sakit menerapkan komunikasi terapeutik kepada pasien. Dalam menjalankan tugas perawat harus senyum, ramah, ikhlasdan tulus hati. Namun pada kenyataannya dalam penerapan budaya organisasi ini tidak sepenuhnya dapat diterapkan oleh perawat, hal ini berdasarkan hasil observasi yang telah dilakukan peneliti bahwa masih ada perawat yang tidak menjalankan komunikasi terapeutik dan masih ada perawat yang manyampaikan informasi dengan raut wajah yang kurang ramah dan tampak lelah. Namun dari hasil jawaban kuesioner yang dilakukan peneliti sebelum dilakukan penelitian terhadap 6 orang perawat pelaksana yang ada diruangan rawat inap yang dilakukan tanggal 6-7 juli 2020 didapatkan hasilnya 50\% perawat menyatakan bahwa memiliki beban kerja yang lebih dengan tugas yang banyak dan membingungkan, pengaruh dari kepemimpinan kepala ruangan hampir $83 \%$ menyatakan pimpinan meningkatkan motivasi dalam bekerja dan meningkatkan partisipasi bawahan dalam bekerja, $16 \%$ perawat menyatakan tidak mengerti dengan komunikasi pimpinan dan kurang meningkatkan partisipasi bawahan dalam bekerja. Sebanyak hampir $90 \%$ perawat setuju dengan budaya organisasi yang diterapkan di Rumah Sakit dr.Esnawan Antariksa. Hasil penelitian prasurvei tersebut menunjukkan adanya perbedaan antara hasil wawancara, observasi, dengan hasil kuesioner sesuai dengan permasalahan penelitian, hal ini kemudian dijadikan pertimbangan untuk pengembangan model penelitian selanjutnya.

Dari uraian permasalahan diatas maka penulis tertarik melakukan penelitian di RSAU dr.Esnawan Antariksa dengan judul "Pengaruh kepemimpinan, beban kerja serta budaya organisasi terhadap stres kerja perawat di ruang rawat inap RSAU dr.Esnawan Antariksa".

\section{Metode Penelitian}

Penelitian ini menggunakan metode penelitian kuantitatif dengan menggunakan pendekatan survey kausalitas. variabel bebas atau variabel independent penelitian ini adalah kepemimpinan (X1), beban kerja (X2) dan budaya organisasi (X3) sementara untuk variabel dependen atau terikat yaitu stres kerja (Y) pada perawat di ruang rawat inap RSUD dr.Esnawan Antariksa. Analisa data dengan menggunakan uji analisis regresif linear berganda. Populasi pada penelitian ini adalah perawat yang bertugas di ruang rawat inap RSAU dr. Esnawan Antariksa, teknik pengambilan sampel system randomsampling, jumlah responden penelitian 76 orang perawat. Jenis data yang digunakan adalah data primer, yaitu data yang diperoleh secara langsung. Pengumpulan data dilakukan dengan menggunakan kuesioner. Skala yang digunakan dalam pengukuran penelitian ini adalah skala likert (dari $1=$ sangat tidak setuju sampai 5 = sangat setuju). Mendapatkan kecenderungan jawaban responden terhadap masing-masing variabel, didasarkan pada nilai skor rata-rata dari hasil perhitungan Three Box Method. Adapun kategori penilaian persepsi responden adalah: Rendah: 12-33, Sedang: 3455, Tinggi: 56-76.

Metode analisis data yang dilakukan dalam penelitian ini adalah dengan menggunakan analisis multivariate dengan uji berganda. Analisis data dimulai setelah data terkumpul, dengan langkah selanjutnya ialah menganalisis data berdasarkan metodeanalisis yang sesuai untuk digunakan. Data yang terkumpul diolah dengan menggunakan alat analisis deskriptif dan kuantitatif. Pengujian analisis data menggunakan Uji t(Uji secara Parsial) dan analisis Uji F (ujisecara simultan). a. Pengukuran Variabel

Pengukuran variable dilakukan
dengan mendistribusikan penyataan
kuesioner sesuai indikator variabel.


Kepemimpinan (X1) menurut (Lussier \& Halabi, 2010) kepemimpinan adalah sifat penerapan pengaruh oleh seorang anggota kelompok atau organisasi terhadap anggota lainnya dengan mendorong kelompok atau organisasi untuk mencapai tujuannya. Dimensi (Bowers \& Seashore, 2004) 1. Bantuan (support) 2. Kemudahan interaksi 3. Pengutamaan tujuan 4. Kemudahan bekerja. Beban kerja (X2) menurut (Gawron et al., 2008) Beban kerja ditetapkan sebagai bagian dari tuntutan tugas, sebagai usaha dan sebagai aktifitas atau pencapaian. Dengan menggunakan dimensi

1. Beban Waktu (time load)

2. Beban usaha mental (mental effortload)

3. Beban tekanan psikologis (psychological stres load).

Budaya Organisasi (X2) menurut (R. J. Robbins, 2003). Budaya organisasi merupakan suatu system nilai yang dipegang dan dilakukan oleh anggota organisasi, sehingga hal yang demikian bisa membedakan organisasi tersebut denganorganisasi lainnya. Dimensi yang digunakan.

1. Inovasi dan pengambilan resiko

2. Perhatian ke hal yang rinci atau detail.

3. Orientasi hasil.

4. Orientasi orang.

5. Orientasi tim.

Stres kerja (Y) menurut (P. D. Robbins \& Morelli, 2014) Stres kerja adalah suatu kondisi ketegangan yang menciptakan adanya ketidakseimbangan fisik dan psikis yang mempengarauhi emosi, proses berfikir dan kondisi seorang karyawan. Dengan menggunakan dimensi

1. Ambigiutas peran

2. Peran berlebih

3. Konflik peran

4. Tuntutan antar pribadi.

\section{Hasil dan Pembahasan}

\section{A. Hasil Penelitian}

1. Deskripsi Responden

Responden mayoritas perawat yang menjadi responden penelitian ini adalah perempuan $(88,2 \%) . \quad 57,9 \%$ responden berusia 31-40 tahun. Karakteristik responden berdasarkan status perkawinan $77,6 \%$ responden sudah menikah. mayoritas berpendidikan terakhir D3 keperawatan $(97,4 \%)$. PNS sebanyak $57,9 \%$. Uji validitas dan reliabilitas pada penelitian menggunakan Pearson Correlation Product Moment. Berdasarkan hasil analisa, untuk item pertanyaan pada variable kepemimpinan, beban kerja, budaya organisasi dan stres kerja adalah valid, dimana didapatkan nilai $r$ hitung $>0,312$. Sedangkan untuk ujireliabilitas pada penelitian ini bahwa Nilai Cronbach's Alpha I semuavariable juga menunjukkan bahwa seluruh pertanyaan reliabel karena nilaiCronbach's Alpha > 0,3494 pada sampel berjumlah 30 orang. Dengan demikian, dapat disimpulkan bahwa pertanyaan dalam kuesioner valid dan reliabel untuk mengukur pengaruh variabel kepemimpinan, beban kerja, dan budaya organisasi terhadap stress kerja perawat.

2. Deskripsi jawaban responden

Analisis deskriptif jawaban responden terhadap variabelindependen (kepemimpinan, beban kerja serta budaya organisasi) dan variabel dependen (stres kerja) yang terdiri dari 54 item pertanyaan. disajikan sebagai berikut:

Tabel 1

\section{Matriks Jawaban Variabel Independen} dan Variabel Dependen

\begin{tabular}{cccccc}
\hline & & \multicolumn{3}{c}{ Score } & \\
\cline { 3 - 5 } No & Variabel & \multicolumn{2}{c}{ RendahSedanTinggi } & Perilaku \\
\hline 1. & Stress kerja & - & V & - & Resiliensi \\
\hline 2. & Kepemimpina & - & - & V & Berkarakter \\
\hline 3. & Beban kerja & - & V & - & Bertanggung \\
\hline
\end{tabular}


Pengaruh Kepemimpinan Kepala Ruangan, Beban Kerja serta Budaya Organisasi Terhadap Stres Kerja Perawat Ruang Rawat Inap Rsau Dr.Esnawan Antariksa

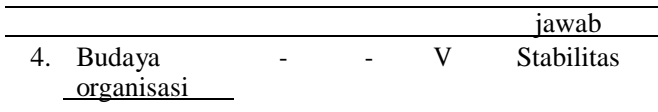

Dari tabel 1 menjelaskan bahwa nilai tertinggi pada semua variabel dalam penelitian ini adalah kepemimpinan dan budaya organisasi memiliki nilai yang tinggi sementara nilai variabel yang lain beban kerja dan stres kerja memiliki nilai yang sedang, hal ini menunjukkan bahwa kepemimpinan kepala ruangan rawat inap di RSAU dr. Esnawan antariksa adalah kepemimpinan yang berkarakter yang memberikan bantuan, motivasi dan mampu menciptakan hubungan yang baik dengan karyawannya hal ini juga disebabkan adanya rasa kebersamaan dalam melaksanakan perintah dan aturan yang ketat dari pimpinan yang lebih tinggi.

Budaya organisasi yang stabil, kuat dan disiplin kerja mempengaruhi perawat dalam bekerja dimana perawat sudah terbiasa dengan budaya yang diterapkan di RSAU dr. Esnawan Antariksa sehingga tingkat stres bagi perawat dalam kategori sedang. Sementara beban kerja dalam batas sedang mempengaruhi mereka dalam bekerja seperti target waktu yang harus diselesaikan dalam melaksanakan pekerjaan, kebingungan dalam menjalankan tugas dan tekanan yang disebabkan oleh konflik peran namun hanya menimbulkan stres perawatdalam kategori sedang dan perawat mampu bertanggung jawab dalammelaksanakan pekerjaannya, sikap inidisebut dengan resiliensi yaitukemampuan Perawat di ruang rawat inap RSAU dr.Esnawan Antariksa beradaptasi dengan kondisi yang tidak menyenangkan saat dihadapkan pada tekanan internal dan eksternal yang ada.
3. Pengajuan Hipotesis

Setelah dilakukan uji asumsi klasik dan terbukti bahwa semua variabel berdistribusi normal dan bebas dari asumsi klasik, maka dilakukan uji hipotesis untuk mengetahui pengaruh seluruh variabel independent secara simultan terhadap stres kerja perawat, maupun pengaruh masing-masing variabel independent secara parsial.

\section{a. Pengaruh Kepemimpinan (X1) \\ Terhadap stres kerja (Y) \\ Untuk \\ variabel}

kepemimipinan (X1) thitung yang diperoleh adalah sebesar $-1,070$ Nilai ini akan dibandingkan dengan nilai ttabel pada tabel distribusi $\mathrm{t}$ dengan $\alpha=0,05$, df $=n-k-1=76-3$ $1=72$, diperoleh nilai t tabel 1,993. Dari nilai diatas didapatkan nilai bahwa nilai thitung X1 sebesar $1,070<1,993$ atau $\alpha=0,05$, dimana sig $=0,288$. Sesuai dengan kriteria pengujian hipotesis bahwa $\mathrm{H} 0$ diterima dan $\mathrm{H} 2$ ditolak artinya variabel kepemimpinan tidak terdapat pengaruh yang signifikan secara parsial terhadap stres kerja.

b. Pengaruh Kualitas Beban kerja (X2) Terhadap stres kerja (Y)

Untuk variabel budaya organisasi (X2) thitung yang diperoleh adalah sebesar 11.494. Nilai ini akan dibandingkan dengan nilai ttabel pada tabel distribusi $\mathrm{t}$ dengan $\alpha=0,05$, df $=n-k-1=76-3$ $1=72$, diperoleh nilai $t$ tabel 1,993 . Dari nilai diatas didapatkan nilai bahwa nilai thitung X2 sebesar $11,494>1,993$ atau $\alpha=0,05$, dimana sig $=0,000$. Sesuai dengan kriteria pengujian hipotesis bahwa $\mathrm{H} 0$ ditolak dan $\mathrm{H} 3$ diterima artinya variabel beban kerja berpengaruh signifikan secara parsial terhadap stres kerja. 
c. Pengaruh Kualitas budaya organisasi (X3) Terhadap stres kerja perawat $(\mathrm{Y})$

Untuk variabel kompensasi (X3) thitung yang diperoleh adalah sebesar -0,888. Nilai ini akan dibandingkan dengan nilai ttabel pada tabel distribusi $\mathrm{t}$ dengan $\alpha$ $=0,05, \quad$ df $=\mathrm{n}-\mathrm{k}-1=76-3-1=72$, diperoleh nilai $t$ tabel 1,993. Dari nilai diatas didapatkan nilai bahwa nilai thitung X3 sebesar $-0,888<$ 1,993 atau $\alpha=0,05$, dimana sig $=$ 0,377 . Sesuai dengan kreteria pengujian hipotesis bahwa $\mathrm{H} 0$ diterima dan $\mathrm{H} 4$ ditolak artinya variabel budaya organisasi tidak terdapat pengaruh yang signifikan secara parsial terhadap stres kerja.

Tabel 2

Hasil Uji F

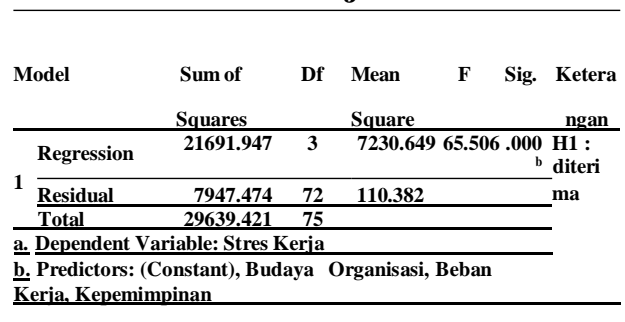

Hasil analisis yang ditunjukkan pada tabel diatas dapat dilihat bahwa nilai $p=0,000$ yang berarti bahwa hasil analisis menerima hipotesis alternatif. Nilai $\mathrm{p}$ yang lebih kecil dari $\alpha 0,05$ berarti bahwa variabel kepemimpinan, beban kerja, dan budaya organisasi secara simultan (Bersama-sama) berpengaruh terhadap stres kerja perawat. Dari Tabel di peroleh nilai $\mathrm{F}$ sebesar 65,506 nilai ini dibandingkan dengan nilai Ftabel pada distribusi F. $\alpha$ $=0,05, \mathrm{df} 1=3$ dan $\mathrm{dF} 2=72$, diketahui Ftabel sebesar 2,73. Dari nilai diatas terlihat bahwa nilai Fhitung yang diperoleh 65,506 > nilai Ftabel sebesar 2,73 , sesuai dengan kriteria pengujian H0 ditolak H1 diterima.Nilai signifikasi antara variabel independen (kepemimpinan, beban kerja, dan budaya organisasi) terhadap variabel dependen (stres kerja) yaitu 0,000 artinya nilai $\alpha<0,05$ dimana variabel kepemimpinan, beban kerja, dan budaya organisasi memberikan pengaruh yang signifikan terhadap stres kerja.

4. Analisis Multi Regresi

Analisis regresi linier berganda dilakukan untuk menguji pengaruh variabel bebas yaitu kepemimpinan, beban kerja serta budaya organisasi terhadap stres kerja perawat. Bedasarkan model persamaan regresi data tersebut disusunlah model regresi linier berganda sebagai berikut:

Tabel 3

\section{Analisis Multi Regresi}

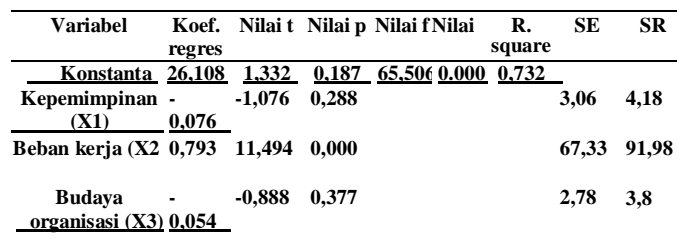

Pada penelitian ini digunakan model persamaan regresi linear berganda berdasarkan tabel 3 diatas sebagai berikut:

$\mathrm{Y}=26,108-0,076$ kepemimpinan $+0,793$ beban kerja -0,064 Budaya Organisasi.

1) Konstanta sebesar 26,108 menyatakan bahwa ketika, kepemimpinan, beban kerja dan budaya organisasi bernilai 0 (nol) dan tidak ada perubahan, maka stres kerja akan bernilai sebesar 26,108.

2) Nilai variabel kepemimpinan (X1) memiliki nilai koefisien regresi sebesar -0,076, artinya ketika kepemimpinan meningkat, sementara beban kerja dan budaya organisasi konstan, maka stress kerja akan menurun sebesar -0,076.

Jurnal Health Sains, Vol 2, No 6, Juni 2021 
Pengaruh Kepemimpinan Kepala Ruangan, Beban Kerja serta Budaya Organisasi Terhadap Stres Kerja Perawat Ruang Rawat Inap Rsau Dr.Esnawan Antariksa

3) Nilai variabel beban kerja (X2) memiliki nilai koefisien regresi sebesar 0,793 artinya ketika beban kerja meningkat, sementara kepemimpinan dan budaya organisasi konstan, maka stres kerja petugas akan meningkat sebesar 0,793 .

4) Nilai variabel budaya organisasi (X3) memiliki nilai koefisien regresi sebesar -0,064, artinya ketika budaya organisasi meningkat, sementara kepemimpinan dan beban kerja konstan, maka stres kerja akan menurun sebesar $-0,064$.

Dari tabel diatas dapat juga dilihat bahwa nilai $\mathrm{R}$ Square sebesar 0,732 mengindikasikan bahwa kepemimpinan, beban kerja, dan budaya organisasi secara Bersamasama mempengaruhi stres kerja perawat sebesar $73,2 \%$ sedangkan sisanya dipengaruhi oleh faktor lain yang tidak diukur dalam penelitian ini. Selain itu dari tabel diatas juga dapat dilihat bahwa sumbangan efektif variabel kepemimpinan terhadap stress kerja perawat sebesar $3,06 \%$ dimana sumbangan relatif kepemimpinan terhadap stres terukur sebesar $4,18 \%$. Sementara itu, beban kerja memiliki sumbangan efektif dan relatif yang besar terhadap stres kerja perawat masing-masing adalah $67,33 \%$ dan 91,98\% sedangkan sumbangan efektif dan relatif budaya organisasi cenderung kecil yaitu 2,78\% dan 3,8\%. Dari data tersebut dapat dilihat bahwa bebankerja lebih dominan berpengaruh terhadap stres kerja perawat. Dari jabaran diatas dapat disimpulkan bahwa secara simultan variabel kepemimpinan, beban kerja, dan budaya organisasi memberikan sumbangan efektif terhadap stres kerja perawat sebesar $73,2 \%$ sedangkan $26,83 \%$ lainnya berasal dari variabel lain yang tidak diukur dalam penelitian ini.

\section{B. Pembahasan}

1. Pengaruh kepemimpinan, beban kerja serta budaya organisasi secara simultan terhadap stres kerja hasil analisis menunjukkan bahwa ketiga variabel independent utama dalam penelitian ini berpengaruh secara simultan terhadap stres kerja.

Hal ini dibuktikan dengan hasil penghitungan uji $\mathrm{F}$ adalah 65,506 dibandingkan dengan nilai $\mathrm{f}$ tabel 2,73 dan nilai $\mathrm{p}=0,000$ yang berarti bahwa hipotesis diterima bahwa kepemimpinan, beban kerja serta budaya organisasi secara simultan berpengaruh terhadap stres kerja. nilai R Square sebesar 0,732 mengindikasikan bahwa kepemimpinan, beban kerja, dan budaya organisasi secara bersama-sama mempengaruhi stres kerja perawat sebesar $73,2 \%$ sedangkan sisanya dipengaruhi oleh faktor lain yang tidak diukur dalam penelitian ini.Berdasarkan hasil penelitian diatas dan didukung oleh penelitian sebelumnya, peneliti berpendapat bahwa kepemimpinan, beban kerja serta budaya organisasi berpengaruh secara signifikan terhadap stres kerja perawat di Ruang rawat inap RSAU dr.Esnawan Antariksa.

Sedangkan berdasarkan analisa distribusi responden dengan menggunakan three box methode, Stres kerja pada perawat di RSAU dr. Esnawan Antariksa masuk dalam kategori sedang dengan nilai indeks yang paling tinggi dirasakan adalah tuntutan antar pribadi. Hal ini menunjukkan bahwa responden merasakan bahwa hubungan kepada 
atasan, antar perawat ataupun dengan teman sejawat kadang menjadi sumber stres kerja dalam melaksanakan pekerjaan. Stres kerja tertinggi kedua adalah peran berlebih. Hal ini mengindikasikan bahwa terkadang responden merasakan bahwa tidak dapat menjalankan pekerjaan dengan optimal karena keterbatasan waktu, sumber daya ataupun energi. Ambiguitas peran juga dinilai dalam kategori sedang berarti bahwa dalam melaksanakan pekerjaan terkadang responden merasa kurang paham terhadap tugas atau peran yang harus dilaksanakannya. Hal ini dapat terjadi ketika penjelasan mengenai tupoksi kurang optimal yang dapat menyebabkan pemahaman dan pelaksanaan tupoksi oleh karyawan juga menjadi kurang optimal. Konflik peran pada perawat. Hal ini menunjukkan bahwa kadang responden merasa tidak dapat memenuhi target pekerjaan dengan optimal karena harus menjalankan tugas lain disaat yang bersamaan. Contoh mendapat tugas piket pos jaga disaat jam dinas dan tugas lain yang berhubung dengan kedinasan selain dari tugas mereka sebagai perawat misalnya di tugaskan turun sebagai tim dukungan kesehatan bencana alam atau kegiatan kemiliteran lainnya. Hal ini didukung oleh teori (Gibson, 2011) stres terjadi karena adanya tekanan (stressor) dan ditempat kerja yaitu stressor lingkungan fisik, stressor individu berupa konflik peran, kepaksaan peranan, beban kerja dan tanggung jawab terhadap orang lain. Hal ini sejalan dengan penelitian terdahulu yang dilakukan oleh (Ari \& Diarta, 2018) dan (Zainaro et al., 2017)

.Pengaruh kepemimpinan, beban kerja, budaya organisasi terhadap stres kerja perawat secara Bersama-sama mempengaruhi stress kerja perawat sebesar $73,2 \%$ dapat dilihat dari tabel bahwa nilai $\mathrm{R}$ square sebesar 0,732 sisanya $26,8 \%$ di pengaruhi oleh factor lain yang tidak diukur dalam penelitian ini, misalnya kompensasi, kepuasan kerja, dan lingkungan kerja yang dikuatkan dengan penelitian terdahulu yang dilakukan oleh (Difayoga \& Yuniawan, 2015).

2. Variabel kepemimpinan (X1) memiliki pengaruh yang negatif terhadap stres kerja

Berdasarkan hasil pengujian hipotesis kedua menunjukkan bahwa kepemimpinan memiliki pengaruhyang negatif dan tidak signifikan terhadap stres kerja perawat. Hal ini dibuktikan dengan hasil regresi linear berganda diperoleh nilai sebesar -1.070 dengan signifikan 0,288 sehingga dapat disimpulkan hipotesis ditolak.

Sedangkan berdasarkan analisa distribusi responden dengan menggunakan three box methode pada penelitian ini bahwa responden merasa kepemimpinan di ruang rawat inap RSAU dr. Esnawan Antariksa dalam kategori tinggi dimana responden merasa puas dengan gaya kepemimpinan yang diasumsikan dengan gaya kepemimpinan militeristik, ternyata hal ini menunjukkan bahwa responden puas akan kepemimpinan yang dirasakan yang berarti asumsi gaya kepemimpinan militeristik tidak terbukti pada penelitian ini karena berdasarkan empat indikator yang dipakai dalam penilaian kepemimpinan, indeks tertinggi adalah indikator bantuan yang berarti bahwa responden merasakan bahwa pimpinan ditempat mereka bertugas senantiasa memperlakukan karyawan sebagai individu yang berharga dan penting. 
Pengaruh Kepemimpinan Kepala Ruangan, Beban Kerja serta Budaya Organisasi Terhadap Stres Kerja Perawat Ruang Rawat Inap Rsau Dr.Esnawan Antariksa

Indikator interaksi yang berarti bahwa manajemen di lingkungan Rumah Sakit Angkatan Udara Dr. Esnawan Antariksa memberikan kesempatan kepada karyawan untuk membina hubungan yang positif, membangun, dan menyenangkan dalam bekerja. Indikator pengutamaan tujuan dan kemudahan bekerja juga dinilai tinggi oleh responden yang menandakan bahwa perawat merasakan bahwa manajemen selalu mendorong antusiasme karyawan dalam mencapai tujuan institusi dan prestasi yang baik.

Hal ini didukung teori (Asmala et al., 2014) bahwa kepemimpinan itu harus mampu memberikan bantuan, kemudahan dalam berinteraksi dan mengutamakan tujuan. Gaya kepemimpinan pada komunitas militer yang cenderung kepemimpinan militeristik tidak ditunjukkan pada penelitian ini. Hal ini juga sejalan dengan penelitian terdahulu yang dilakukan oleh (Cahyani et al., 2019). Penelitian ini juga didukung oleh (Mamonto, 2013) terdapat pengaruh leadership terhadap stres kerja perawat di Rumah Sakit dimana semakin baik kategori leadership maka akan menurunkan stres kerja perawat Penelitian (Mamonto, 2013) diruang rawat inap RSUD Bitung, diketahui bahwa sebesar $84,9 \%$ perawatpelaksana mengisi kecenderungan gaya kepemimpinan kepala ruangan adalah demokratik dan $15,1 \%$ perawat mengisi gaya kepemimpinan kepala ruangan adalah otokratik. Sedangkan, untuk tingkat stres kerja perawat, sebesar $92,5 \%$ perawat mengalami tingkat stres ringan dan 7,5\% perawat mengalami tingkat stres sedang.

3. Variabel beban kerja (X2) memiliki pengaruh positif terhadap stress kerja (Y)
Pengaruh beban kerja terhadap stres ditemukan signifikan dibuktikan dengan nilai $p$ 0,000 yang berarti bahwa semakin tinggi nilai beban kerja maka semakin tinggi stres kerja perawat. Nilai R Square sebesar 0,633 menunjukkan bahwa beban kerja mempengaruhi stres kerja perawat sebesar $63,3 \%$. Berdasarkan hasil analisis dapat dilihat rata-rata indeks variabel beban kerja termasuk dalam kategori sedang. Berdasarkan nilai tersebut dapat dikatakan bahwa responden merasakan bahwa beban kerja perawat di Rumah Sakit Angkatan Udara dr. Esnawan Antariksatermasuk sedang. Dilihat dari indikator yang digunakan dalam penilaian beban kerja, beban waktu memiliki indikator tertinggi. Meskipun masuk dalam indeks kategori sedang, responden merasakan bahwa beban waktu merupakan faktor tertinggi yang dirasakan dalam bekerja. Target waktu yang ditetapkan dalam penyelesaian pekerjaan seperti banyaknya pasien dan tindakan yang harus diselesaikan dalam satu shift menjadi faktor utama dalam beban kerja yang dirasakan responden.

Faktor tekanan psikologis dan usaha mental memiliki nilai indeks yang tidak jauh berbeda. Beban tekanan psikologis dirasakan responden meskipun dengan kategori sedang yang berarti bahwa kebingunan atau rasa frustasi yang berkaitan dengan tugas kadang dialami karyawan. Contoh rotasi karyawan yang cepat dan penempatan karyawan tidak sesuai dengan kompetensinya. Beban usaha mental juga dinilai responden dalam kategori sedang yang berarti responden merasakan bahwa kompleksitas tugas yang diberikan manajemen harus dilakukan dengan perhatian, konsentrasi, dan tuntutan mental yang 
cukup tinggi agar tugas tersebut dapat dijalankan dengan baik dan menghasilkan output yang optimal. Dimana kompleksitas tugas ini berdasarkan Sistem penugasan pada perawat di RSAU dr. Esnawan Antariksa. Penugasan dengan model kerja tim dimana ada kepala ruangan memimpin beberapa orang perawat pelaksana. Tenaga keperawatan di Rumah sakit ini memiliki keunikan yaitu terdapat tenaga perawat yang militer dan non militer / PNS kemhan. Penugasannya tidak hanya sebagai perawat di Rumah sakit terkadang mendapat tugas terkait perannya sebagai anggota TNI atau PNS kemhan dalam waktu yang bersamaan seperti menjadi bantuan kesehatan dalam kegiatan pemeriksaan kesehatan di kesatuan, latihan militer, dukungan kesehatan bencana alam dan piket dikesatuan hal ini juga berpengaruh terhadap tingkat stres pada perawat.

Hal ini didukung oleh teori (Gawron et al., 2008) dimana beban kerja dapat dilihat dari beban waktu yaitu jumlah waktu yang tersedia dalam melaksanakan tugas atau kerja, berapa banyak usaha mental dalam melaksanakan kerja kemudian tekanan psikologis , kebingungan dan frustasi yang dialami dalam bekerja.Hal ini juga sejalan dengan beberapa hasilpenelitian terdahulu yang dilakukanoleh (Karimi et al., 2014), (Satrini et al., 2017) yang menjelaskan bahwa beban kerja berlebih berpengaruh positif terhadap stres kerja, semakin tinggi beban kerja semakin tinggi stres kerja.

4. Variabel budaya organisasi (X3) memiliki pengaruh negatif terhadap variabel stres kerja $(\mathrm{Y})$

Pengaruh budaya organisasi juga berpengaruh negatif signifikan terhadap stress kerja perawat, menunjukkan bahwa semakin baik budaya organisasi akan menurunkan stres kerja perawat. Berdasarkan nilai regresi linear berganda diperoleh nilai 0.888 dengan nilai signifikan 0,377 sehingga dapat disimpulkan hipotesis ditolak.

Berdasarkan analisa distribusi responden dengan menggunakan three box methode Indeks variabel budaya organisasi, termasuk dalam kategori tinggi. Kelima indikator yang dipakai dalam pengukuran budaya organisasi yaitu inovasi dan pengambilan resiko, perhatian pada hal yang rinci atau detail, orientasi hasil, orang dan tim juga masing-masing menunjukkan indeks dalam kategori tinggi. Orientasi terhadap orang menjadi indikator yang paling tinggi dinilai oleh responden yang berarti bahwa responden menilai bahwa institusi senantiasa mempertimbangkan individu yang akan terdampak dalam setiap keputusan atau kebijakan yang diambil dan yang akan diterapkan Contoh pegawai yang mempunyai keterbatasan fisik dikurangi tugas piketnya.

Indikator kedua tertinggi yaitu perhatian ke hal rinci atau detail hal ini menunjukkan bahwa responden merasakan institusi telah menerapkan budaya dimana semua karyawan dituntut untuk menjalankan tugas dengan tepat, cermat dan memperhatikan hal-hal detail dalam bekerja. Indikator ketiga tertinggi adalah orientasi tim yang menunjukkan bahwa responden menilai bahwa kerja tim di RSAU. dr. Esnawan Antariksa lebih diutamakan dibandingkan dengan kerja individu dalam penyelesaian tugas atau kegiatan. Inovasi dan pengambilan resiko juga dinilai tinggi oleh responden yang mengindikasikan 
Pengaruh Kepemimpinan Kepala Ruangan, Beban Kerja serta Budaya Organisasi Terhadap Stres Kerja Perawat Ruang Rawat Inap Rsau Dr.Esnawan Antariksa

bahwa penerapan budaya kerja inovatif dan berani dalam mengambil resiko telah biasa diterapkan dalam institusi. Sementara itu, orientasi hasil dinilai sedang oleh respoden yang berarti bahwa hasil bukanlah fokus yang paling utama dari manajemen dalam menilai hasil kerja, namun juga mempertimbangkan teknik dan proses dalam penyelesaian kerja atau tugas yang dilakukan karyawan.Hal ini didukung oleh teori (P. D. Robbins \& Morelli, 2014) bahwa budaya organisasi yang menerapkan seberapa jauh organisasi mampu memberikan dukungan terhadap karyawan untuk berinovasi, menunjukkan ketepatan analisis, dukungan organisasi terhadap proses pencapaian hasil dan menerapkan budaya dimana karyawan bekerja sesuai dengan arahan dan melakukan pekerjaan secara bersamasama.

Hal ini juga sejalan dengan penelitian terdahulu yang dilakukanoleh (Yuwono et al., 2014) yang menjelaskan bahwa adanya hubungan signifikan antara budaya organisasi dengan stress kerja. Hal ini juga seiring dengan penelitian (Sahrani et al., 2014) mengemukakan ada pengaruh negatif budaya organisasi terhadap stres kerja. Berdasarkan hasil penelitian diatas dan didukung oleh penelitian sebelumnya, peneliti berpendapat bahwa kepemimpinan, beban kerja serta budaya organisasi berpengaruh secara signifikan terhadap stres kerja perawat di Ruang rawat inap RSAU dr.Esnawan Antariksa.

Penelitian ini memperoleh data temuan, Adapun temuan yang ditemukan adalah di antara variabel bebas yang terdiri dari kepemimpinan, beban kerja serta budaya organisasi yang paling berpengaruh terhadap variabel terikat stres kerja adalah variabel beban kerja. Perawat di ruang rawat inap RSAU dr. Esnawan Antariksa merasakan beban kerja merupakan faktor yang paling dominan yang menimbulkan stres kerja diantaranya beban waktu yang merupakan target waktu yang ditetapkan dalam menyelesaikan pekerjaan. Kepemimpinan kepala ruangan tidak signifikan mempengaruhi stres kerja pada perawat diruang rawat inap RSAU dr.Esnawan Antariksa. Kepemimpinan kepala ruangan di ruang rawat inap RSAU dr. Esnawan Antariksa memberikan bantuan, dapat merangsang antusiasme bawahan terhadap tugas-tugas kelompok dan dapat mengatakan hal-hal yang dapat menumbuhkan kepercayaan bawahan terhadap kemampuannya untuk menyelesaikan tugas dan mencapai tujuan. Kepemimpinan seperti kepemimpinan yang mempunyai karakter yang kuat. Pada budaya organisasi terhadap stres kerja perawat juga tidak memberikan pengaruh yang signifikan. Budaya organisasi di RSAU dr. Esnawan Antariksa mempunyai budaya yang kuat dan stabil ,perawat rawat inap merasakan institusi telah menerapkan budaya dimana semua karyawan dituntutuntuk menjalankan tugas dengan tepat, cermat dan memperhatikan hal yang detail dalam bekerja serta inovatif.

\section{Kesimpulan}

Berdasarkan analisis data dan pembahasan hasil penelitian, dapat disimpulkan variabel kepemimpinan, beban kerja serta budaya organisasi secara langsung atau simultan berpengaruh terhadap streskerja perawat ruang rawat inap RSAU dr. Esnawan Antariksa, yang artinya semakin baik kepemimpinan, beban kerja serta budaya organisasi maka stres kerja akan semakin rendah. Variabel kepemimpinan berpengaruh terhadap stres kerja perawat ruang rawat inap RSAU dr. Esnawan Antariksa, dimana pengaruhnya negatif yang artinya semakin 
baik kepemimpinan maka akan semakin turun stres kerjanya. Variabel beban kerja secara langsung berpengaruh terhadap stres kerja perawat di ruang rawat inap RSAU dr Esnawan Antariksa, dimana pengaruhnya positif yang artinya semakin tinggi beban kerja maka semakin tinggi tingkat stres kerja perawat. Beban kerja yang di rasakan oleh perawat ruang rawat inap RSAU dr. Esnawan Antariksa yaitu adanya kekurangan waktu dalam menyelesaikan pekerjaan yang ada dan jenis pekerjaan yang banyak dan terkadang melakukan pekerjaan diluar tupoksi. Beban kerja yang berlebihan ini bisa menjadi sumber stres kerja perawat yang utama sehingga berpengaruh terhadap produktifitas perawat dan tentu saja berpengaruh terhadap produktifitas rumah sakit itu sendiri.

\section{BIBLIOGRAFI}

Aini, S. N. (2013). Faktor Risiko Yang Berhubungan Dengan Kejadian Gizi Lebih Pada Remaja Di Perkotaan. Unnes Journal Of Public Health, 2(1). Google Scholar

Ari, I. B., \& Diarta, I. M. (2018). Penerapan Model Pembelajaran Berbasis Proyek (Pjbl) Terhadap Hasil Video Digital Story Telling Landskap Budaya Subak. Prosiding Seminar Nasional Pendidikan Biologi, 1(1), 691-695. Google Scholar

Asmala, E., Bowers, D. G., Autio, R., Kaartokallio, H., \& Thomas, D. N. (2014). Qualitative Changes Of Riverine Dissolved Organic Matter At Low Salinities Due To Flocculation. Journal Of Geophysical Research: Biogeosciences, 119(10), 1919-1933. Google Scholar

Bowers, D. G., \& Seashore, S. E. (2004). Predicting Organizational Effectiveness With A Four-Factor Theory Of Leadership. The International Library Of Leadership, 2, 133-158. Google Scholar
Cahyani, L. G., Kustriyani, M., \& Mariyati, M. (2019). Gaya Kepemimpinan Dengan Stres Kerja Perawat Di Ruang Rawat Inap. Jurnal Ners Widya Husada,6(3), 97-102. Google Scholar

Difayoga, R., \& Yuniawan, A. (2015). Pengaruh Stres Kerja, Kepuasan Kerja, Dan Lingkungan Kerja TerhadapKinerja Perawat (Studi Pada Rs Panti Wilasa Citarum Semarang). DiponegoroJournal Of Management, 250-259. Google Scholar

Gawron, D., Mazouffre, S., Sadeghi, N., \& Héron, A. (2008). Influence Of Magnetic Field And Discharge Voltage On The Acceleration Layer Features In A Hall Effect Thruster. Plasma Sources Science And Technology, 17(2), 25001. Google Scholar

Gibson, D. G. (2011). Enzymatic Assembly Of Overlapping Dna Fragments. Methods In Enzymology, 498, 349-361. Google Scholar

Karimi, R., Omar, Z. B., Alipour, F., \& Karimi, Z. (2014). The Influence Of Role Overload, Role Conflict, And Role Ambiguity On Occupational Stress Among Nurses In Selected Iranian Hospitals. International Journal of Asian Social Science, 4(1), 34-40. Google Scholar

Lussier, R. N., \& Halabi, C. E. (2010). A Three-Country Comparison Of The Business Success Versus Failure Prediction Model. Journal Of Small Business Management, 48(3), 360-377. Google Scholar

Mamonto, S. (2013). Keragaman Dan Karakteristik Bio-Ekologis Anggrek Di Kawasan Cagar Alam Gunung Ambang Sub-Kawasan Kabupaten Bolaang Mongondow Timur Berdasarkan Ketinggian Tempat. Skripsi, 1(431409069). Google Scholar 
Pengaruh Kepemimpinan Kepala Ruangan, Beban Kerja serta Budaya Organisasi Terhadap Stres Kerja Perawat Ruang Rawat Inap Rsau Dr.Esnawan Antariksa

Robbins, P. D., \& Morelli, A. E. (2014). Regulation Of Immune Responses By Extracellular Vesicles. Nature Reviews Immunology, 14(3), 195-208. Google Scholar

Robbins, R. J. (2003). Phenolic Acids In Foods: An Overview Of Analytical Methodology. Journal of Agricultural And Food Chemistry, 51(10), 28662887. Google Scholar

Sahrani, R., Matindas, R. W., Takwin, B., \& Mansoer, W. W. (2014). The Role Of Refl Ection Of Difficult Life Experiences On Wisdom. Karya Ilmiah Dosen, 40(2), 316. Google Scholar

Satrianegara, M. F. (2014). Organisasi Dan Manajemen Pelayanan Kesehatan: Teori Dan Aplikasinya Dalam Pelayanan Puskesmas Dan RumahSakit. Salemba Medika. Google Scholar

Satrini, I. D. A. K., Riana, I. G., \& Subudi, I. M. (2017). Pengaruh Work Overload, Ambiguitas Peran Dan Budaya Organisasi Terhadap Stres Kerja. EJurnal Ekonomi Dan Bisnis Universitas Udayana. Google Scholar
Siringoringo, D. M., \& Fujino, Y. (2015). Seismic Response Analyses Of An Asymmetric Base-Isolated Building During The 2011 Great East Japan (Tohoku) Earthquake. Structural Control And Health Monitoring, 22(1), 71-90. Google Scholar

Yana, D. (2015). Stres Kerja Pada Perawat Instalasi Gawat Darurat Di Rsud Pasar Rebo Tahun 2014. Jurnal Administrasi Rumah Sakit Indonesia, 1(2). Google Scholar

Yuwono, M., Su, S. W., Guo, Y., Moulton, B. D., \& Nguyen, H. T. (2014).

Unsupervised Nonparametric Method For Gait Analysis Using A Waist-Worn Inertial Sensor. Applied Soft Computing, 14, 72-80. Google Scholar

Zainaro, M. A., Isnainy, U. C. A. S., Furqoni, P. D., \& Wati, K. (2017). Pengaruh Motivasi Kerja Terhadap KinerjaPerawat Pelaksana Di Ruang Rawat Inap Rumah Sakit Umum Daerah Alimuddin Umar Kabupaten LampungBarat Tahun 2017. Holistik Jurnal Kesehatan, 11(4), 209215. Google Scholar

\section{Copyright holder:}

Desi Sofiana, Sandra Dewi, Muhamad Arrozi (2021)

First publication right:

Jurnal Health Sains

This article is licensed under:

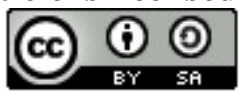

